\title{
Effects of Feed and Water Intakes on Whole Blood Viscosity and Plasma Osmolality in Broiler Chickens
}

\author{
Weitong ZHOU $^{1}$, Masanori FujITA and Sadaki Yamamoto ${ }^{2}$ \\ Faculty of Applied Biological Science, Hiroshima University, \\ Higashi-Hiroshima, 739-8528, Japan
}

\begin{abstract}
Two experiments were carried out to determine the effect of feed and water intakes on whole blood viscosity in broiler chickens. In experiment 1 , three feeding levels $(25,50$ and $75 \mathrm{~g} /$ bird) were provided to three groups of birds at $08.00 \mathrm{~h}$, respectively. After feeding, each bird was allowed to drink $100 \mathrm{~m} l$ water at $09.00 \mathrm{~h}$. In experiment 2 , two levels of water ( 50 and $150 \mathrm{~m} l /$ bird) were given to two group birds, after $50 \mathrm{~g} / \mathrm{bird}$ feed was taken, at $09.00 \mathrm{~h}$. WBV and plasma osmolality (PO) increased with the increase of feed intake, and decreased with time after feeding. However, in $25 \mathrm{~g}$ feed intake birds, $\mathrm{PO}$ increased with time after feeding. Plasma protein concentration (PPC) was $(\mathrm{P}<0.05)$ higher at 50 and $75 \mathrm{~g}$ than at $25 \mathrm{~g}$ feeding level. No significant differences were found in haematocrit (HCT) and plasma viscosity (PV) between feeding levels. There was no significant difference in PPC, HCT or PV between the two drinking levels. PO had a significantly $(\mathrm{P}<0.05)$ lower value at $150 \mathrm{~m} l$ compared to at $50 \mathrm{~m} l$ at $09.30 \mathrm{~h}$, although no significant difference was found in WBV. Moreover, WBV and PO tended to decrease with time at $50 \mathrm{ml}$, while to increase at $150 \mathrm{ml}$. As described above, WBV and PO increased with the increase of feed intake, but their changes with time after feeding were related to a water/feed ratio.
\end{abstract}

(Jpn. Poult. Sci., 36 : 148-154, 1999)

Key words : blood viscosity, broiler chicken, feed intake, plasma osmolality, water intake

\section{Introduction}

It is well known that heat-exposure induces an increase in water intake and a reduction in feed intake in broiler chickens. It has been noticed that whole blood viscosity (WBV) and haematocrit (HCT) decreased significantly when broilers were exposed to high temperature (ZHOU et al., 1997). Such decrease is likely to be related to the reduction in feed intake and the increase in water intake. Hocking et al. (1994) reported that WBV and plasma viscosity (PV) were significantly lower in chronically restricted-fed broiler breeders than in ad libitum-fed birds. ZHou et al. (1998 a) found that WBV and HCT, compared to ad libitum-fed broilers, were markedly lower in the birds deprived of feed and water for $15 \mathrm{~h}$, and tended to be higher after deprivation of feed and water for $21 \mathrm{~h}$.

Under the conditions of feeding and drinking ad libitum, red blood cells, HCT, plasma protein concentration (PPC) of broiler decreased during high ambient temper-

Received October 26, 1998 Accepted December 15, 1998

${ }^{1}$ Present address : Poultry Research Farm, Hosoya \& Co., Ltd., 590-2, Tanno, Ogasa-Cho, Ogasa-Gun, Shizuoka-Ken, 437-1501, Japan.

${ }^{2}$ To whom correspondence should be address. E-mail : yamasad@ipc.hiroshima-u.ac.jp 
ature (Deaton et al., 1969 ; Kubena et al., 1972 ; DonKoh, 1989 ; Yahav et al., 1997 ; Zhou et al., 1997, 1998 a). However, many reports indicated that water withdrawal induced an increase in HCT and PPC, even though the animals were kept under thermoneutral environment. In broilers reared under standard conditions, there was no change in HCT within $6 \mathrm{~h}$ after feed and water withdrawal, but an increase after feed and water withdrawal exceeded $6 \mathrm{~h}$ (ScotT et al., 1983). KoIKE et al. (1983) reported that HCT was significantly higher in chickens deprived of water for $24 \mathrm{~h}$ or more, than in control group birds. A significant reduction, with the increase in feed restriction period, was observed in red and white blood cells and thrombocyte numbers together with significant increase in mean cell haemoglobin and mean cell volume in the broiler chickens, in which early feed restriction ( $14 \mathrm{~g} / \mathrm{d} /$ bird) was carried out for 6,10 or 14 days from 6 d-old (MAXWell et al., 1991).

As described above, feed and water restrictions influence haematology. However, how the extent of feed or water intake influences haematology and blood rheology has not been studied sufficiently. This study, therefore, was designed to determine the effects of feed and water intakes on WBV, HCT, PV, PPC and plasma osmolality (PO) of broiler chickens under thermoneutral environment in order to explain whether the decrease in WBV due to heat exposure (ZHOU et al., 1997) could be related to feed and water intakes.

\section{Materials and Methods}

Commercial male broiler chickens (Chunky) were used in this study. After 40-dold, the birds were kept in individual cages $(25 \times 45 \times 38 \mathrm{~cm})$ at an ambient temperature of $20.0 \pm 1.0^{\circ} \mathrm{C}$ and a relative humidity of $60-70 \%$, and provided twice with a commercial grower ration (ME $13.2 \mathrm{MJ} / \mathrm{kg}, \mathrm{CP} 180 \mathrm{~g} / \mathrm{kg}$; New Power, Nichiwa Sangyo Co. Ltd., Japan) at 08.00 and $16.00 \mathrm{~h}$ each day. They were trained and allowed to take feed as much as possible within $1 \mathrm{~h}$ from 08.00 and $16.00 \mathrm{~h}$, respectively, before experiment. Water of $200 \mathrm{~m} l$ was supplied to each bird from $09.00 \mathrm{~h}$ each day. The lighting pattern was $14 \mathrm{~L}: 10 \mathrm{D}$.

\section{Experiment 1}

This experiment was conducted to determine the effect of feed intake. Twentyfour birds were divided into 3 groups ( 8 birds/group) at random. Each group of birds were provided with 25,50 or $75 \mathrm{~g}$ of feed for each bird at $08.00 \mathrm{~h}$ at 51 -d-old (body weight : $3.10 \pm 0.11 \mathrm{~kg}$ ), respectively. After the feed was taken, each bird was allowed to drink $100 \mathrm{~m} l$ water by a vinyl tube (id $1.5 \mathrm{~mm}$, od $3 \mathrm{~mm}$ ), which was inserted into crop from mouth, at $09.00 \mathrm{~h}$.

\section{Experiment 2}

This experiment was conducted to determine the effect of water intake. Each bird was provided with $50 \mathrm{~g}$ of feed at $08.00 \mathrm{~h}$ at 51 -d-old (body weight : $3.05 \pm 0.15 \mathrm{~kg}$ ). Sixteen birds were divided into 2 groups ( 8 birds/group) at random. One group birds, after feed was taken, was allowed to drink $50 \mathrm{ml} /$ bird water at $09.00 \mathrm{~h}$ as Experiment 1 , 
while the other group birds $150 \mathrm{ml} /$ bird.

Blood sampling and the measurements of blood parameters

Approximately $1.5 \mathrm{ml}$ of blood was collected using a syringe containing a drop of heparin solution (1000 IU heparin/ml, Novo Heparin, Marion Mereru Dau Co., Ltd, Osaka, Japan) from a wing vein of each bird at $09.30,12.30$ and $15.30 \mathrm{~h}$, respectively. The blood was used for the measurement of WBV. WBV was measured using a Cannon-Manning Semimicroviscometer (150, Kusano Scientific Instrument MFG Co., Ltd, Tokyo, Japan) as described by Zно et al. (1997). Plasma was obtained by centrifuging for $15 \mathrm{~min}$ at $3,500 \mathrm{rpm}$ after the measurement of $\mathrm{WBV}$, then used for the measurement of viscosity and protein concentration. PV was measured by the same technique as WBV. PPC was measured using a clinical protein meter (T 2-Se, Atago Co., Ltd, Tokyo, Japan). PO was determined using a semi-micro osmometer (Knauer, KG Dr. Herbert Knauer \& Co. GmbH, Berlin, Germany) as described by ZHou et al. (1998 b). HCT was determined using microhematocrit capillary tubes (Terumo VC-H $075 \mathrm{H}$, Terumo Co., Ltd, Tokyo, Japan) by centrifuging for $5 \mathrm{~min}$ at $12,000 \mathrm{rpm}$.

\section{Statistical analyses}

A two-way analysis of variance was used to determine the significance with feed intake or water intake and blood sampling time. Tukey's multiple comparison test (IsHimura, 1992) was used to test the significance between means.

\section{Results}

\section{Experiment 1}

Changes in HCT, WBV, PV, PPC and PO with feed intake are shown in Table 1. WBV increased with the increase of feed intake and was significantly $(\mathrm{P}<0.05)$ higher at $75 \mathrm{~g}$ than at 50 and $25 \mathrm{~g}$ feeding level at any sampling time. In addition, WBV decreased with time after feeding at 50 and $75 \mathrm{~g}$ feeding levels. HCT tended to reduce with time, but no marked differences were found between feeding levels. There was no difference in PV between feeding levels or between sampling time points. At 09.30 $\mathrm{h}, \mathrm{PPC}$ was significantly $(\mathrm{P}<0.05)$ higher at 75 and $50 \mathrm{~g}$ than at $25 \mathrm{~g}$ feed intake. PO increased with the increase of feed intake, and decreased with time after feeding, while increased with time at $25 \mathrm{~g}$.

\section{Experiment 2}

Table 2 shows changes in HCT, WBV, PV, PPC and PO with water intake. No marked difference was found in HCT, PV or PPC between the levels of water intake. WBV was similar between 50 and $150 \mathrm{ml}$ water intake at $09.30 \mathrm{~h}$, while significantly (P $<0.05$ ) higher at $150 \mathrm{ml}$ than at $50 \mathrm{ml}$ drinking level at 12.30 and $15.30 \mathrm{~h}$. Moreover, WBV decreased with time after drinking at $50 \mathrm{~m} l$ water intake, while tended to increase at $150 \mathrm{ml}$. PO was significantly $(\mathrm{P}<0.05)$ higher at $50 \mathrm{ml}$ than at $150 \mathrm{ml}$ at $09.30 \mathrm{~h}$, and decreased with time after drinking at $50 \mathrm{~m} l$, while tended to increase at $150 \mathrm{~m} l$. 
Table 1. Changes in haematocrit, whole blood viscosity, plasma viscosity, plasma protein concentration and plasma osmolality of broilers with feed intake

\begin{tabular}{cccc}
\hline \hline & \multicolumn{3}{c}{ Feed intake $(\mathrm{g})$} \\
\cline { 2 - 4 } & 25 & 50 & 75 \\
\hline Haematocrit (\%) & & \\
$9: 30$ & $27.7 \pm 0.7$ & $28.3 \pm 0.8$ & $28.5 \pm 0.9$ \\
$12: 30$ & $27.8 \pm 0.6$ & $27.1 \pm 0.8$ & $27.5 \pm 1.1$ \\
$15: 30$ & $27.4 \pm 0.5$ & $26.2 \pm 0.8$ & $27.3 \pm 1.1$ \\
Whole blood viscosity (cp) & & \\
$9: 30$ & $2.258 \pm 0.083^{\mathrm{A}}$ & $2.423 \pm 0.080^{\mathrm{Ab}}$ & $2.582 \pm 0.126^{\mathrm{B}}$ \\
$12: 30$ & $2.329 \pm 0.057^{\mathrm{A}}$ & $2.399 \pm 0.070^{\mathrm{Ab}}$ & $2.493 \pm 0.153^{\mathrm{B}}$ \\
$15: 30$ & $2.331 \pm 0.065^{\mathrm{A}}$ & $2.202 \pm 0.077^{\mathrm{Aa}}$ & $2.414 \pm 0.129^{\mathrm{B}}$ \\
Plasma viscosity $(\mathrm{cp})$ & & \\
$9: 30$ & $0.977 \pm 0.013$ & $1.001 \pm 0.014$ & $0.998 \pm 0.008$ \\
$12: 30$ & $0.986 \pm 0.011$ & $0.977 \pm 0.010$ & $0.991 \pm 0.011$ \\
$15: 30$ & $0.985 \pm 0.015$ & $0.977 \pm 0.013$ & $0.977 \pm 0.015$ \\
Plasma protein concentration $(\mathrm{g} / 100 \mathrm{~m} l)$ & & \\
$9: 30$ & $2.9 \pm 0.1^{\mathrm{A}}$ & $3.2 \pm 0.1^{\mathrm{Bb}}$ & $3.2 \pm 0.1^{\mathrm{Bb}}$ \\
$12: 30$ & $2.9 \pm 0.1$ & $3.0 \pm 0.1^{\mathrm{a}}$ & $3.0 \pm 0.1^{\mathrm{a}}$ \\
$15: 30$ & $2.9 \pm 0.2$ & $2.9 \pm 0.1^{\mathrm{a}}$ & $2.9 \pm 0.1^{\mathrm{a}}$ \\
Plasma osmolality $\left(\mathrm{mOsm} / \mathrm{kg} \mathrm{H} \mathrm{H}_{2} \mathrm{O}\right)$ & & \\
$9: 30$ & $292.3 \pm 1.9^{\mathrm{Aa}}$ & $307.0 \pm 2.5^{\mathrm{Bc}}$ & $313.7 \pm 2.2^{\mathrm{Cb}}$ \\
$12: 30$ & $293.3 \pm 2.5^{\mathrm{Aab}}$ & $297.7 \pm 3.1^{\mathrm{Bb}}$ & $304.1 \pm 2.8^{\mathrm{Ca}}$ \\
$15: 30$ & $296.4 \pm 2.1^{\mathrm{Ab}}$ & $291.1 \pm 2.0^{\mathrm{Ba}}$ & $305.6 \pm 4.7^{\mathrm{Ca}}$ \\
\hline
\end{tabular}

Mean \pm SE $(n=8)$.

Each bird was forced to drink water $100 \mathrm{ml}$ after eating ceased at $09.00 \mathrm{~h}$.

$\mathrm{A}, \mathrm{B}, \mathrm{C}$ : Significant differences between different superscripts within the same row $(\mathrm{P}<0.05)$.

a,b,c : Significant differences for each variable between different superscripts within the same column $(\mathrm{P}<0.05)$.

\section{Discussion}

The fact that long-term feed restriction induced a reduction in WBV (Hocking et $a l$. , 1994) was also observed in short-term fed-restricted birds in this study. WBV increased significantly with the increase of feed intake. However, no marked differences were found in HCT and PV, which are closely related to WBV (CHIEN, 1982 ; SturkiE and GRIminger, 1986 ; SMith and KAMPINe, 1990 ; MAEDA, 1996), between feeding levels. This may be caused by a larger number of smaller erythrocytes in circulation or a larger number of component parts in plasma in the birds fed a larger amount of feed. Hocking et al. (1994) reported that red blood cells and plasma triglyceride tended to be higher in ad libitum-fed fat line birds than in restricted birds. PO, which reflects solute concentration in plasma, increased with the increase of feed intake in this study. The increase in PO probably induces a water shift from blood cells to plasma, resulting in a smaller cell size. In addition, there was no marked difference in PV, even though 
Table 2. Changes in haematocrit, whole blood viscosity, plasma viscosity, plasma protein concentration and plasma osmolality of broilers with water intake

\begin{tabular}{ccc}
\hline \hline & \multicolumn{2}{c}{ Water intake $(\mathrm{ml})$} \\
\cline { 2 - 3 } Haematocrit (\%) & 150 \\
\cline { 2 - 3 } $9: 30$ & $27.0 \pm 0.7$ & $28.4 \pm 0.6$ \\
$12: 30$ & $26.4 \pm 0.7$ & $27.4 \pm 0.5$ \\
$15: 30$ & $26.4 \pm 0.7$ & $27.1 \pm 0.7$ \\
Whole blood viscosity (cp) & \\
$9: 30$ & $2.372 \pm 0.062$ & $2.367 \pm 0.044$ \\
$12: 30$ & $2.320 \pm 0.095^{\mathrm{A}}$ & $2.473 \pm 0.076^{\mathrm{B}}$ \\
$15: 30$ & $2.239 \pm 0.060^{\mathrm{A}}$ & $2.438 \pm 0.060^{\mathrm{B}}$ \\
Plasma viscosity (cp) & & \\
$9: 30$ & $1.010 \pm 0.012$ & $0.995 \pm 0.018$ \\
$12: 30$ & $1.013 \pm 0.032$ & $0.993 \pm 0.022$ \\
$15: 30$ & $1.000 \pm 0.005$ & $1.002 \pm 0.026$ \\
Plasma protein concentration $(\mathrm{g} / 100 \mathrm{~m} l)$ & $3.3 \pm 0.2$ \\
$9: 30$ & $3.3 \pm 0.1$ & $3.2 \pm 0.2$ \\
$12: 30$ & $3.1 \pm 0.1$ & $3.3 \pm 0.2$ \\
$15: 30$ & $3.1 \pm 0.1$ & \\
Plasma osmolality (mOsm $\left./ \mathrm{kg} \mathrm{H}_{2} \mathrm{O}\right)$ & $300.4 \pm 2.1^{\mathrm{Bb}}$ & $291.3 \pm 2.8^{\mathrm{Aa}}$ \\
$9: 30$ & $295.0 \pm 1.6^{\mathrm{a}}$ & $298.6 \pm 3.4^{\mathrm{b}}$ \\
$12: 30$ & $291.9 \pm 2.9^{\mathrm{a}}$ & $298.0 \pm 4.4^{\mathrm{b}}$ \\
$15: 30$ & &
\end{tabular}

Mean $\pm \mathrm{SE}(\mathrm{n}=8)$.

Feed intake was $50 \mathrm{~g} / \mathrm{bird}$ from $8: 00$ to $9: 00$.

$\mathrm{A}, \mathrm{B}$ : Significant differences between different superscripts within the same row $(\mathrm{P}<0.05)$.

a,b : Significant differences for each variable between different superscripts within the same column $(\mathrm{P}<0.05)$.

PPC, related to PV (ZHOU et al., $1998 \mathrm{a}$ ), was significantly higher at 50, $75 \mathrm{~g}$ feeding levels than at $25 \mathrm{~g}$ at $09.30 \mathrm{~h}$ (Table 1). This may indicate that $\mathrm{PV}$ is not susceptible to the change in PPC as observed in a previous study (ZHOU et al., $1998 \mathrm{~b}$ ).

WBV and HCT tended to decrease with time after feeding, irrespective of feed intake. This phenomenon may be caused by the following reasons. Firstly, this may be due to a diurnal variation in haematology. ZHOU et al. (1998 a) observed that WBV, HCT and red blood cells were lowest at $15.00 \mathrm{~h}$ in the birds being able to access to feed and water ad libitum. Secondly, the higher PO may induce that some water enters into blood vessels from interstitial space and alimentary tract, resulting in hemodilution. PPC and PO decreased with time at 75 and $50 \mathrm{~g}$ feeding levels may reflect this view. However, at $150 \mathrm{~m} l$ drinking or $25 \mathrm{~g}$ feeding level, WBV and PO increased with time after drinking or feeding. Such changes may be associated with an increase in the relative water intake to feed. Water intake was relatively excessive to feed intake at $150 \mathrm{ml}$ drinking or $25 \mathrm{~g}$ feeding level, subsequent to induce an increased urine 
production. In colostomised hen, OKumuRa et al. (1977) and VAN KAMPEN (1981) showed that the increased water intake increased urine production and did not change water content in faeces, indicating that excessive water from alimentary tract was excreted from kidney. It was noticed that watery stools were excreted 6 times for $25 \mathrm{~g}$ feeding or $150 \mathrm{~m} l$ drinking level until $15.30 \mathrm{~h}$, while not found for $75 \mathrm{~g}$ feeding or $50 \mathrm{~m} l$ drinking level. The increases in WBV and PO with time at $25 \mathrm{~g}$ feeding and $150 \mathrm{~m} l$ drinking level may indicate that the reduced WBV and PO due to relatively excessive water intake recovers because of an increased urine production.

In conclusion, WBV and PO increased with feed intake. However, their changes with time after feeding were related to a water/feed.

\section{References}

Chien, S. (1982) Hemorheology in clinical medicine (a review). Clinical Hemorheology, 2 : 137-142. DeAton, J.W., ReECE, F.N. and TARVER, W.J. (1969) Hematocrit, hemoglobin and plasma-protein levels of broilers reared under constant temperatures. Poultry Science, 48 : 1993-1996.

DonkoH, A. (1989) Ambient temperature : a factor affecting performance and physiological response of broiler chickens. International Journal of Biometeorology, 33 : 259-265.

Hocking, P.M., MAxwell, M.H. and Mitchell, M.A. (1994) Haematology and blood composition at two ambient temperatures in genetically fat and lean adult broiler breeder females fed $a d$ libitum or restricted throughout life. British Poultry Science, 35 : 799-807.

IshimURA, S. (1992) Analysis of Variance, pp. 136-161 (Tokyo, Tokyotosho Press).

KoIKE, T.I., PRYOR, L.R. and NELDON, H.L. (1983) Plasma volume and electroly tes during progressive water deprivation in chickens (Gallus domesticus). Comparative Biochemistry and Physiology, $74 \mathrm{~A}: 83-87$.

KubENA, L.F., MAY, J.D., ReEcE, F.N. and DeAton, J.W. (1972) Hematocrit and hemoglobin of broilers as influenced by environmental temperature and dietary iron level. Poultry Science, $51: 759-$ 763.

MAEDA, N. (1996) Erythrocyte rheology in microcirculation (a review). Japanese Journal of Physiology, $46: 1-14$.

Maxwell, R.H., Robertson, G.W., ANderson, I.A., Dick, L.A. and LynCh, M. (1991) Haematology and histopathology of seven-week-old broilers after early food restriction. Research in Veterinary Science, $50: 290-297$.

Oкumura, J., TASAKI, I. and SaIto, K. (1977) Relation between ambient temperature and relative humidity and wet droppings in chickens. Japanese Poultry Science, $14: 217-222$.

SCOTT, T.R., SATTERLEE, D.G. and JACOBS-PERRY, L.A. (1983) Circulating corticosterone responses of feed and water deprived broilers and Japanese quail. Poultry Science, $62: 290-297$.

SMITH, J.J. and KAMPINE, J.P. (1990) Circulatory Physiology - the essentials (3rd edition), pp. 16-30. (Williams \& Wilkins, Baltimore, USA).

StURKIE, P.D. and Griminger, P. (1986) Body fluids : Blood, in : STURKIE, P.D. (Ed) Avian Physiology, 4th edition, pp. 102-129 (New York, Springer-Verlag).

VAN KAMPEN, M. (1981) Water balance of colostomised and non-colostomised hens at different ambient temperatures. British Poultry Science, 22 : 17-23.

Yahav, S., Straschnow, A., Plavnik, I. and Hurwitz, S. (1997) Blood system response of chickens to changes in environmental temperature. Poultry Science, $76: 627-633$.

Zhou, W.T., Fujita, M., Ito, T. and Yамамото, S. (1997) Effects of early heat exposure on thermoregulatory responses and blood viscosity of broilers prior to marketing. British Poultry Science, 38 : 301-306.

Zhou, W.T., FuJiTA, M. and Yamamoto, S. (1998 a) Effects of food and water withdrawal and high temperature exposure on diurnal variation in blood viscosity of broiler chickens, British Poultry Science, 39 : 156-160.

Zhou, W.T., Fujita, M., Yamamoto, S., Iwasaki, K., Ikawa, R., Oyama, H. and HoriKawa, H. (1998 b) 
Effects of glucose on drinking water on the changes in whole blood viscosity and plasma osmolality of broiler chickens during high temperature exposure. Poultry Science, 77 :644647.

\title{
ブロイラーの血液粘度と血漿浸透圧に及ぼす飼料摂取量 と飲水量の影響
}

\author{
周＼cjkstart維統*・藤田正範・山本禎紀 \\ 広島大学生物生産学部, 東広島市 $739-8528$
}

高温曝露による血液粘度の低下の原因を究明するため に本研究では, ブロイラーの全血粘度 (WBV) に及ぼす 飼料摂取量と飲水量の影響について検討した。実験 1 で は, 8 時に 1 羽当たり 25,50 または $75 \mathrm{~g}$ の飼料をそれ ぞれ 8 羽ずつに給与した。飼料摂取後, 9 時に 1 羽当た り $100 \mathrm{~m} l$ の水を強制的に給与した。実験 2 では, 8 時に 1 羽当たり $50 \mathrm{~g}$ の飼料を摄取させ，9時に 50 または 150 $\mathrm{ml}$ の水をそれぞれ 8 羽ずつに強制的に給与した。WBV 及び血漿浸透圧 (PO) は, 飼料摄取量の増加に伴い増加 したが, その後, 経時的に低下した。ただし, $25 \mathrm{~g}$ での PO は逆に経時的に増加した。血漿蛋白濃度 (PPC) は, $25 \mathrm{~g}$ に比べ 50 及び $75 \mathrm{~g}$ で有意に（P<0.05）高くなっ
た。ヘマトクリット（HCT）及び血漿粘度 (PV) は, 飼 料摄取量間に有意差は認められなかった。PPC, HCT 及 び PVは，飲水量間に有意差は認められなかった。9 時 半の值で, $\mathrm{PO}$ は, 飲水量 $50 \mathrm{~m} l$ に比べ $150 \mathrm{~m} l$ で有意に $(\mathrm{P}<0.05)$ 低かった。また, WBV 及び $\mathrm{PO}$ は, $50 \mathrm{ml}$ で 経時的に低下したが, $150 \mathrm{ml}$ では逆に増加した。以上の ように, WBV 及び PO は飼料摄取量の増加に伴い増加 し，その経時的な変化は飼水比と関係していることが分 かった。

(家禽会誌, $36: 148-154,1999)$ キーワード：血液粘度，ブロイラー，飼料摂取量，血漿 浸透圧, 飲水量

* 現所属 : 株式会社ホソヤ家禽研究所, テ437-1501 静岡県小笠郡小笠町丹野 590-2 